\title{
Progress in Studies on the Etiology and Serologic Diagnosis of Enzootic Bovine Leukosis
}

\author{
MANFred Mussgay and OsKar-RÜGER KaAdeN ${ }^{1}$
}

I. Introduction . . . . . . . . . . . . . . . . . . . . . . 43

II. Definition of the Disease . . . . . . . . . . . . . . . . . . . . . 44

III. Etiologic Studies. . . . . . . . . . . . . . . . . . . . . . . . 44
A. Epizootiological Aspects of the Disease . . . . . . . . . . . . . . . 44
B. Experimental Transmission. . . . . . . . . . . . . . . . . . . . 45
C. Production of Bovine Type C Particles in Cell Culture . . . . . . . . . 46
1. Lymphocyte Cultures . . . . . . . . . . . . . . . . . . . . . . 46
2. Cell Lines . . . . . . . . . . . . . . . . . . . . . . . . . 46
3. Syncytia Formation . . . . . . . . . . . . . . . . . . . . . . . 48
4. Transmission Experiments . . . . . . . . . . . . . . . . . . . . . 49

IV. Properties of Bovine Type C Particles . . . . . . . . . . . . . . . . . 50

A. Biochemical and Biophysical Properties . . . . . . . . . . . . . . . 50

B. Morphology . . . . . . . . . . . . . . . . . . . . . . . . . . . 55

C. Genetic Relatedness to Host DNA . . . . . . . . . . . . . . . . . 56

D. Host Spectrum . . . . . . . . . . . . . . . . . 57

E. Relationship to other Retroviridae . . . . . . . . . . . . . . . . . 58

V. Serologic Diagnosis . . . . . . . . . . . . . . . . . . . . . . . . 59

A. Agar Gel Immunodiffusion . . . . . . . . . . . . . . . . . . . . 59

B. Complement Fixation . . . . . . . . . . . . . . . . . . . . . . . 63

C. Immunofluorescence . . . . . . . . . . . . . . . . . . . . . . 64

D. Radioimmunoassay . . . . . . . . . . . . . . . . . . . . 66

E. Indirect Immunoperoxidase Test . . . . . . . . . . . . . . . . . .66

F. Detection of BLV and BLV-Antigen . . . . . . . . . . . . . . .67 67

VI. Prospective Studies. . . . . . . . . . . . . . . . . . . . . 67

References ...................... . . 68

\section{Introduction}

Enzootic leukosis of domestic cattle (enzootic bovine leukosis) causes severe enconomic loss. The disease occurs throughout the world, though it appears that geographic differences exist. Epizootiologic and transmission studies performed in the past suggested an infectious agent of the disease, and a virus was considered as the main candidate. Progress supporting this view has been made during recent years in research on type $\mathrm{C}$ tumor viruses that cause leuke-

\footnotetext{
${ }^{1}$ Federal Research Institute for Animal Virus Diseases, Paul Ehrlich Str. 28, D-7400 Tübingen, Federal Republic of Germany
} 
mias and sarcomas in fowl, mice, rats, hamsters, pigs, cats, baboons, woolly monkies and gibbon apes but not before Miller et al. (1969) described type $\mathrm{C}$ particles in short-term lymphocyte cultures derived from leukotic cows, an association between type $\mathrm{C}$ particles and bovine leukosis was firmly based on experimental data. However, such lymphocyte cultures were not well suited for the characterization of bovine type $\mathrm{C}$ particles, and therefore, it was a great breakthrough in the research on bovine leukosis etiology when van der Maaten et al. (1974) were successful in establishing long-term cultures that continued to release adequate numbers of infectious particles. The present review is an attempt to summarize developments since 1969 concerning the properties of bovine type $\mathrm{C}$ particles and their use in serologic diagnosis of bovine leukosis. Readers interested in preceding studies on these topics and in the history, epizootiology, pathology, and clinical manifestations of bovine leukosis are referred to the reviews written by Bendixen (1965), Wiesner (1967), Wittmann and Urbaneck (1969a, b), and Abramova et al. (1974).

\section{Definition of the Disease}

Enzootic bovine leukosis is characterized by neoplasia of the lymphocyte-forming tissue and its occurrence as multiple cases within a herd. In cattle, it is the most common type of lymphocytic leukosis (or lymphosarcoma, or lymphomatosis, to give common synonyms). Other forms of lymphocytic leukosis are classified by epizootiologic, clinical, and pathoanatomic criteria (Bendixen, 1965) - sporadic bovine leukosis (juvenile leukosis, leukosis sporadica juvenils) with the calf form (calf multicentric type), the thymic form (adolescent type), and cutaneous leukosis (leukosis sporadica cutanea). All these forms have a low incidence.

It is appropriate to mention briefly some of the more important clinical features of enzootic bovine leukosis. The incubation time varies considerably and is described as being between 200 days (Tolle, 1965) and 7 years (Straub and Weinhold, 1971). The disease may develop in two phases. A persistent lymphocytosis characterizes the first phase, mainly due to an increase of surface immunoglobulin-bearing lymphocytes (Muscoplat et al., 1974; Weiland and Straub, 1975), followed in about $10 \%-30 \%$ of the cases by the occurrence of leukotic tumors. At this stage the animals are usually 4-8 years old. However, there are also cases in which the tumorous phase is not proceeded by a lymphocytosis (aleukemic tumorous leukosis).

\section{Etiologic Studies}

\section{A. Epizootiological Aspects of the Disease}

Epizootiologic observations and other studies on bovine leukosis performed during the last 50 years provide cumulative evidence that the disease is primar- 
ily caused by an infectious and transmissible agent (Bendixen, 1976). It was reported on the basis of clinical, haematologic, and histopathologic criteria that bovine leukosis occurred as single or multiple cases among certain cattle families in several parts of some, mainly European, countries. The disease was clinically apparent as lymphoproliferative neoplasia or, more commonly, as a persistent lymphocytosis. Sporadic leukosis of calves or of skin leukosis remained very rare events. The observations on multiple bovine leukosis in related cow families or in some breedings led to the assumption that hereditary factors or genetic disposition may play an important role in the pathogenesis of the disease. Bovine leukosis showed little tendency to spread to other parts of Europe, though by the early $1960 \mathrm{~s}$, it was detected in most European and some non-European countries. The occurrence of the disease in cattle populations was thought to be correlated with importation of clinically inapparently infected or genetically suspectible breeding cattle. The epizootiologic observations concerning the incidence and spreading of the disease were fully consistent with those experiences previously reported.

In Sweden, an interesting observation regarding the epizootiology and transmission was made. A statistically significant increase in the incidence of bovine leukosis was found in cattle farms that used calf blood to vaccinate against piroplasmosis. The assumption that the calf blood vaccine may have contained the etiologic agent of bovine leukosis was later reinforced, since use of piroplasmosis vaccine from leukosis-free cattle farms prevented further spread of bovine leukosis. A comprehensive review regarding epizootiologic, clinical, and histopathologic findings was published in 1969 by Wittmann and Urbaneck.

All these epizootiologic observations mentioned had a stimulating effect on the number of transmission experiments to demonstrate that bovine leukosis is transmitted from dam to offspring by in utero-infection or infectious colostrum feeding (vertical transmission); or infection of cattle by contact, oral, or parenteral infectious (horizontal transmission).

\section{B. Experimental Transmission}

The vertical transmission of bovine leukosis is defined as intrauterine diaplacentar infection of fetuses by infected cows, regardless of whether dams showed clinical symptoms or had only latent infections. Besides prenatal, postnatal infections of the offspring by the dam are considered as vertical transmission. Different experiments showed that feeding calves with infectious colostrum contributed to the spread of the disease. The epizootiologic observations and controlled transmission experiments therefore, suggested that offspring from leukotic or leukosis virus-infected cows generally should be considered as infected or suspicious. Direct transfer of bovine leukosis from cows to fetuses by intrauterine infection helps to explain the clusterlike incidence of bovine leukosis in certain cow families.

The second mode of infection is defined as horizontal transmission. Direct infection of susceptible cattle (mainly calves) by leukotic or clinically inapparently infected animals may be mediated by blood, feces, urine, amniotic fluid, 
and eye or nasal secretions from leukotic or infected cattle. Occasional transfer of infectious virus may also occur by veterinary measures, e.g., vaccination. New-born calves in their postnatal phase were found to be very susceptible to infection. No experimental evidence is available at present, however, to demonstrate that sperma from infected bulls is infectious and may transmit bovine leukosis through artificial insemination.

It can be suggested that bovine leukosis follows the characteristics of a typical infectious virus disease. The agent can infect cattle in which it multiplies and may be transmitted to progeny by nongenetic vertical or horizontal transmission, though nothing suggests that it enters the germ line and is integrated in the cellular genome.

\section{Production of Bovine Type C Particles in Cell Culture}

\section{Lymphocyte Cultures}

Type $\mathrm{C}$ viruses have previously been identified as etiologic agents of transmissible lymphoid neoplasia or leukemias in several animal species. With regard to bovine leukosis, although virus-like particles were described in tissues of leukotic animals by electron microscopy, their etiologic role in the disease could not be proven (Ueberschär, 1963; Dutcher et al., 1964). A breakthrough was achieved when Miller et al. (1969) detected type C particles resembling mammalian leukemia viruses in ultrathin sections of lymphocytes obtained from multiplecase herds, experimentally infected cattle, and from sporadic aleukemic lymphosarcomas. Subsequent reports by other workers (Ferrer et al., 1971; Calafat et al., 1974; Weiland et al., 1974) presented more conclusive evidence of budding processes associated with these particles. Most budding particles were observed between 12 and $24 \mathrm{~h}$ after the initiation of lymphocyte cultures, which suggested that virus assembly might be synchronized with early stages of cell growth. It was also consistently observed that the production of virus-like particles in the cultivated cells seemed to be independent of the presence of mitogens. Taken together with studies to be described later, these observations provided grounds to designate these particles as bovine leukemia virus (BLV).

\section{Cell Lines}

Before 1974, a key problem in the characterization and biochemical analysis of type $\mathrm{C}$ particles detected in bovine leukosis material was the lack of permanently established cell lines which continuously released adequate concentrations of virus particles. Recent developments permit large-scale production and purification procedures as well as sensitive quantitative assays for virus-specific activities. In 1974, van der Maaten et al. established long-term cultures from fetal lamb tissue (kidney or spleen cells) by cocultivation with virus-producing bovine donor cells. Fetal lamb kidney (FLK) or spleen (FLS) cells were found to release appreciable quantities of BLV and these cultures have been widely used since their introduction for morphologic, biochemical, and serologic studies. 
Table 1. Cultivated cells of different origin infected with BLV by inoculation with BLV or by cocultivation with BLV-infected cells

\begin{tabular}{|c|c|c|c|c|}
\hline Host cell origin & $\begin{array}{l}\text { Desig- } \\
\text { nation }\end{array}$ & $\begin{array}{l}\text { Passage } \\
\text { level }\end{array}$ & $\begin{array}{l}\text { BLV detected } \\
\text { by }\end{array}$ & References \\
\hline $\begin{array}{l}\text { Bovine blood } \\
\text { lymphocytes }\end{array}$ & - & Short-term & $\begin{array}{l}\text { EM, IFA, ID, } \\
\text { RDDP }\end{array}$ & $\begin{array}{l}\text { Miller et al., 1969; } \\
\text { Schmidt et al., 1970; } \\
\text { Ferrer et al., 1971; } \\
\text { Kaaden et al., 1972; } \\
\text { Stock and Ferrer, 1972; } \\
\text { Paulsen et al., 1973; } \\
\text { Weiland et al., 1974; van } \\
\text { der Maaten et al., 1974; } \\
\text { Calafat et al., 1974 }\end{array}$ \\
\hline $\begin{array}{l}\text { Bovine blood } \\
\text { lymphocytes }\end{array}$ & NBC & Long-term & EM & Ferrer et al., 1972 \\
\hline $\begin{array}{l}\text { Bovine embryonic } \\
\text { lung }\end{array}$ & Co 76 & Long-term & IFA, EM, ID & Ressang et al., 1974 \\
\hline $\begin{array}{l}\text { Bovine embryonic } \\
\text { spleen }\end{array}$ & BESP & Short-term & $\begin{array}{l}\text { IFA, Syncytia } \\
\text { RDDP }\end{array}$ & $\begin{array}{l}\text { Graves and Ferrer, 1976; } \\
\text { van der Maaten et al., } \\
1974\end{array}$ \\
\hline Fetal lamb thymus & A 77 & Long-term & ID, CF & Onuma et al., 1976 \\
\hline Fetal lamb spleen & FLS & Long-term & $\begin{array}{l}\text { IFA, Syncytia, } \\
\text { RDDP, CF, } \\
\text { ID }\end{array}$ & $\begin{array}{l}\text { Graves and Ferrer, 1976; } \\
\text { van der Maaten et al., } \\
1974 ; \text { Ressang et al., 1974 }\end{array}$ \\
\hline Fetal lamb kidney & FLK & Long-term & ID, CF, RDDP & $\begin{array}{l}\text { van der Maaten and Mil- } \\
\text { ler, } 1976\end{array}$ \\
\hline Caprine ovary & S-743 & Short-term & $\begin{array}{l}\text { IFA, Syncytia, } \\
\text { RDDP }\end{array}$ & $\begin{array}{l}\text { Graves and Ferrer, 1976; } \\
\text { Diglio and Ferrer, } 1976\end{array}$ \\
\hline $\begin{array}{l}\text { Fetal canine } \\
\text { thymus }\end{array}$ & $\mathrm{FCf}_{2} \mathrm{Th}$ & Short-term & $\begin{array}{l}\text { IFA, Syncytia, } \\
\text { RDDP, EM }\end{array}$ & $\begin{array}{l}\text { Graves and Ferrer, 1976; } \\
\text { Diglio and Ferrer, } 1976\end{array}$ \\
\hline Bat lung & Tb1 Lu & Long-term & $\begin{array}{l}\text { IFA, Syncytia, } \\
\text { RDDP, EM }\end{array}$ & $\begin{array}{l}\text { Graves and Ferrer, 1976; } \\
\text { Diglio and Ferrer, } 1976\end{array}$ \\
\hline Fetal rhesus lung & DBS-FRhL & Short-term & $\begin{array}{l}\text { IFA, Syncytia, } \\
\text { RDDP }\end{array}$ & $\begin{array}{l}\text { Graves and Ferrer, 1976; } \\
\text { Diglio and Ferrer, } 1976\end{array}$ \\
\hline Chimpanzee spleen & РT001Sp & Short-term & IFA, Syncytia & $\begin{array}{l}\text { Graves and Ferrer, 1976; } \\
\text { Diglio and Ferrer, } 1976\end{array}$ \\
\hline $\begin{array}{l}\text { Human embryonic } \\
\text { lung }\end{array}$ & WI-38 & Long-term & $\begin{array}{l}\text { IFA, Syncytia, } \\
\text { RDDP }\end{array}$ & $\begin{array}{l}\text { Graves and Ferrer, 1976; } \\
\text { Diglio and Ferrer, 1976 }\end{array}$ \\
\hline
\end{tabular}

Abbreviations: $\mathrm{CF}=$ complement fixation; $\mathrm{EM}=$ electron microscopy $; \mathrm{ID}=$ immunodiffusion; IFA = immunofluorescent antibody; RDDP $=$ RNA-dependent DNA polymerase; Syncytia = syncytia formation

In the meantime, a variety of bovine, (Ressang et al., 1974; Graves and Ferrer, 1976); ovine, (van der Maaten et al., 1974; Paulsen et al., 1973; Onuma et al., 1976; Graves and Ferrer, 1976; Ressang et al., 1974); caprine, (Graves and Ferrer, 1976); canine, (Graves and Ferrer, 1976); simian, (Graves and Ferrer; 1976); bat; human, and nonhuman primate (Graves and Ferrer, 1976) cell origins 
had been proven by different techniques to propagate BLV in low to moderate quantities, as summarized in Table 1. In a systematic analysis of both primary cells and established lines from different species, Graves and Ferrer (1976) using serology and electron microscopy reported high yields of BLV in two different cell cultures from bat lungs. In a similar study, Onuma et al. (1976) used fetal lamb thymus as host cells to propagate BLV. In most cases, embryonic tissues from lamb or bovine donors were infected with leukemic lymphocytes, infected long-term cultures cells, or with cell-free virus particles to establish virus-producing long-term cultures. Once established, infected cells showed a continuous increase in virus production after several initial passages, although after a certain period in culture, their virus yield declined. However, FLK cells, even after 70 passages in cultures, have been observed (Frenzel, personal communication) to produce relatively high quantities of BLV. Established long-term cultures of bovine or ovine origin have now been widely introduced for BLV production and have nearly completely replaced primary or established long-term cultures of lymphocytes (Ferrer et al., 1971).

\section{Syncytia Formation}

In numerous studies, the cultivation of lymph node cells or peripheral blood lymphocytes failed to demonstrate specific cytologic alterations in leukotic cells. The described findings such as lymphocyte adsorption, formation of giant cells and syncytia, cell transformation, piling up, appearance of cytoplasmic vacuoles and inclusion bodies, phagocytosis, or chromosomal aberrations were either found to be unspecific for bovine leukosis or caused by contaminating microorganisms, e.g. mycoplasmas (see review Wittmann and Urbaneck, 1969). The formation of syncytia using human embryonic lung cells (WI-38) as indicator cells by cocultivation with peripheral lymphocytes from leukemic cattle was described by Cornefert-Jensen et al. (1969). The simultaneous detection of virus particles led to the assumption that syncytia formation may be related to the presence of virus particles. In an extended series of experiments, syncytia formation was described as the specific cytopathogenic expression of the bovine and ovine leukemia virus genomes (Ferrer and Diglio, 1976; Diglio and Ferrer, 1976; Ogura et al., 1977). Monolayer cells of human embryonic lung or bovine embryonic spleen cells showed syncytia formation if cocultivated with leukemic lymphocytes, BLV-infected cells or gradient-purified virus. After incubation for several days and staining, cells containing five or more nuclei were considered as syncytia. The concentration of the syncytia-inducing factor in leukemic cells or in BLV preparations was found to be directly correlated with the number of syncytia formed. The specificity of the cytopathogenic effect (CPE) was further shown by neutralization experiments in which specific antisera from leukemic cattle were able to inhibit the syncytia formation, while control experiments demonstrated the absence of any contaminating virus, e.g., bovine syncytial virus (BSV), maedi-visna-like R-29, infectious bovine rhinotracheitis (IBR), bovine virus diarrhea (BVD), as well myoplasma in the inoculum. Use of WI-38 cells reduced the possible effect of BSV, IBR, or BVD viruses on the syncytia formation, although the bovine embryonic spleen cells were considered to be 
more sensitive for BLV detection. Other cytologic findings also included mononucleated cells with cytoplasmic vacuoles and nuclear fragmentation.

The mechanism of syncytia formation by isolated BLV or BLV-infected cells so far has not been investigated. The findings of Diglio and Ferrer (1976) showed that syncytia formation was independent of virus production and not correlated with an increase of mitotic figures. The authors therefore suggested that syncytia formation is likely to involve cell fusion rather than endomitosis. On the other hand, syncytia formation certainly arises from some BLV-specific functions, since UV-irradiation, heating at $56^{\circ} \mathrm{C}$ for $30 \mathrm{~min}$ and freeze-thawing completely inactivated the syncytia-inducing activity of BLV preparations.

The ability of bovine leukemia virus to induce syncytia formation in monolayer cells of bovine or human tissues was used to develop a sensitive and rapid diagnostic assay for both virus infectivity and antibody neutralization (Ferrer and Diglio, 1976). The test provided quantitative results and was successfully applied for direct virus detection in lymphocytes and tumor tissues of leukotic cattle.

\section{Transmission Experiments}

A review of the published evidence of bovine leukosis transmission indicates that successful transmission to cattle was achieved before the identification of the bovine leukemia virus (see review Wittmann and Urbaneck, 1969). Schmidt (personal communication) stated that at least 320 calves and adult animals had been used until 1974 for experimental infection. From these, 117 animals had been successfully infected by experimental application of cellular material from leukotic donors (blood or tumor cell suspension), cell-free inocula from leukotic cattle (serum, plasma), or their in vitro cultured cells (supernatant from cultured leukocytes). Transmission of the disease could also be observed after feeding milk or colostrum from leukemic cows to calves, or by contact exposure of susceptible animals to leukemic cattle. The experiences gained from the transmission experiments as well as from epizootiologic observations created the basic concept that bovine leukosis is mediated by both vertical and horizontal transmission (see Sect. III. A.).

The introduction of reliable and reproducible virologic (Miller et al., 1969; Ferrer et al., 1971 ; van der Maaten et al., 1974; Ressang et al., 1974) and serologic (Miller and Olson, 1972; Miller and van der Maaten, 1974; Ferrer et al., 1972) techniques initiated defined studies by which propagation of inoculated virus particles in experimental animals and their serologic responses could be followed in a more direct way. In a preliminary communication Schmidt (1970) reported transmission experiments with leukocyte cultures from leukemic cattle. The studies were later completed when type $C$ particles were detected in mitogenstimulated lymphocyte cultures from three cattle with experimentally induced lymphocytosis (Schmidt et al., 1970). Miller et al. (1972) included the electronmicroscopic examination of lymphocytes from donor and recipients in their transmission studies. Sixteen calves were inoculated by parenteral injection of, or oral exposure to, tumor cells from lymphosarcomas or with cultivated lymphocytes between one and 26 days after birth. One animal received cell-free 
tissue culture supernatant at 4 days old. Type $C$ particles were detected electronmicroscopically in lymphocyte cultures from all experimental calves from two to 13 months postinoculation, and there was a clear correlation between the age of the recipients and first appearance of virus particles in cultivated blood cells. The genetic heterogeneity of the experimental animals may account for the fact that only five of 16 calves developed a persistent lymphocytosis between four and 13 months after exposure. Schmidt et al. (1975) performed transmission experiments in which nine day old calves received cell-free culture medium from PHA-stimulated lymphocytes. Three calves were found to be infected based on hematologic and electron-microscopic examinations followed by serologic tests. Kaaden et al. (1976) reported transmission experiments in which colostrum-deprived calves were inoculated by the intraabdominal route with the supernatant of cultivated lymphocytes and found that a two-month incubation period was necessary before an increased number of blood lymphocytes could be detected. The financial and logistic problems arising from keeping experimental cattle may be overcome in part by using sheep as experimental animals. Apparently bovine leukosis can be transmitted readily from cattle to sheep (Wittmann and Urbaneck, 1969). Recent studies performed in the USA (Olson et al., 1972) and Germany (Paulsen et al., 1974) confirmed the transmissibility of leukemia or lymphosarcoma from cattle to sheep. Of 13 sheep, 11 showed positive results in virus particle production although only five showed lymphosarcoma on post-mortem examination. A prominent characteristic was thymus involvement in all clinical cases which suggested that this organ plays an important role in lymphoid neoplasia pathogenesis.

\section{Properties of Bovine Type C Particles}

\section{A. Biochemical and Biophysical Properties}

By physical and chemical characterization, avian and mammalian oncornaviruses are spherical, enveloped, single-stranded RNA viruses. Their sedimentation coefficient is about $600 \mathrm{~S}-700 \mathrm{~S}$ with an overall buoyant density of $1.15-1.17 \mathrm{~g} / \mathrm{ml}$ for intact virus particles. Chemical analysis revealed $60 \%$ protein, $35 \%$ lipid, $2.2 \%$ nucleic acids (among them $0.04 \%$ DNA) and $0.5 \%$ carbohydrate (see review Bauer, 1974). Based on recent findings, BLV was classified as a member of the mammalian type $C$ oncoviruses (Fenner, 1976). The reported data for its sedimentation coefficient and buoyant density are in the same range as for other mammalian oncornaviruses. The corresponding densities were estimated to be $1.16 \mathrm{~g} / \mathrm{ml}$ in sucrose and $1.12 \mathrm{~g} / \mathrm{ml}$ in metrizamide solutions (Weiland et al., 1974; Kettmann et al., 1975).

Although there is still a considerable lack of information specific for BLV concerning its chemical structure, RNA, and structural proteins when compared with the data for oncornaviruses in general (Bolognesi and Bauer, 1970; Quigley et al., 1971), some progress has been made in elucidating the antigenic composition of the virus. Whereas pilot experiments started with cultured lym- 
phocytes of leukemic cattle (Miller et al., 1969; Schmidt et al., 1970; Ferrer et al., 1971; Kaaden et al., 1972), long-term cultures of fetal lamb (van der Maaten et al., 1974; Onuma et al., 1976) or bat lung cells (Graves and Ferrer, 1976) latently infected with BLV are now most commonly used as sources for virus isolation and purification. Because BLV multiplies in these cells without any distinct cytopathic effect, the optimum time for virus harvest and yield can only be evaluated by determining other virus-specific activities. The following methods have been described for either virus or antigen detection: (1) serologic and electron-microscopic techniques (van der Maaten et al., 1974; Graves and Ferrer, 1976), (2) reverse transcriptase activity (Dietzschold et al., 1974; Gilden et al., 1975) and, (3) syncytia formation (Ferrer and Diglio, 1976). For the isolation and quantitation of noninfectious subviral components agar gel immunodiffusion (ID) (Miller and Olson, 1972) or complement fixation (CF) (Miller and van der Maaten, 1974) tests must be performed. The reverse transcriptase assay carried out as a simultaneous detection test also may be used for virus quantitation, indirect detection of high molecular weight BLV-RNA, and isolation of complementary DNA (Kettmann et al., 1975; Kettmann et al., 1976).

Several techniques have been employed to concentrate and purify BLV particles from infected tissue culture cells or supernatants. Clarification of the culture fluid by low-speed centrifugation, followed by sedimentation in the ultracentrifuge and sucrose gradient centrifugation, have been widely used for BLV purification (Weiland et al., 1974; Callahan et al., 1976; Onuma et al., 1976; Devare et al., 1976; Kaaden et al., 1976; Deshayes et al., 1977). Alternatively, BLV precipitation by ammonium sulfate (McDonald and Ferrer, 1976), polyethyleneglycol 6000 (Paulsen et al., 1974), or continuous flow rotor centrifugation and isopycnic banding in sucrose (Gilden et al., 1975) have also provided comparable purified virus preparations. Because of low virus titers in culture fluids, Kettmann et al. $(1975,1976)$ found homogenization and sucrose gradient centrifugation necessary to extract BLV components from the cytoplasmic fraction of infected cells. So far, no precise data concerning the ratio of infectious to physical particles or the antigenic activity per milligram of purified BLV have been communicated.

Little is known about the genome composition and structure of BLV RNA. The oncornavirus RNA consists of a high molecular weight component sedimenting in a bulk of $60 \mathrm{~S}-70 \mathrm{~S}$. At least four additional low molecular weight species can be extracted from purified oncornaviruses (see review Bauer, 1974). In radioactive incorporation experiments with a tritiated RNA precursor, Weiland et al., (1974) found labelled uridine activity in a particle fraction with a density of $1.16 \mathrm{~g} / \mathrm{ml}$. These authors isolated a 35S RNA component from labelled BLV particles but failed to demonstrate 70S RNA. Kettmann et al. (1975) were able to demonstrate a high molecular weight RNA by an indirect approach. Using the simultaneous detection of the reverse transcriptase and the virus RNA as endogenous template, an RNA-reverse transcriptase complex sedimenting near $70 \mathrm{~S}$ was identified. The negative outcome of other experiments to extract typical high molecular weight RNA from BLV may be explained by low virus titers and the lability of the virus particles as shown by electronmicroscopic examination (see Sect. IV. B.). 

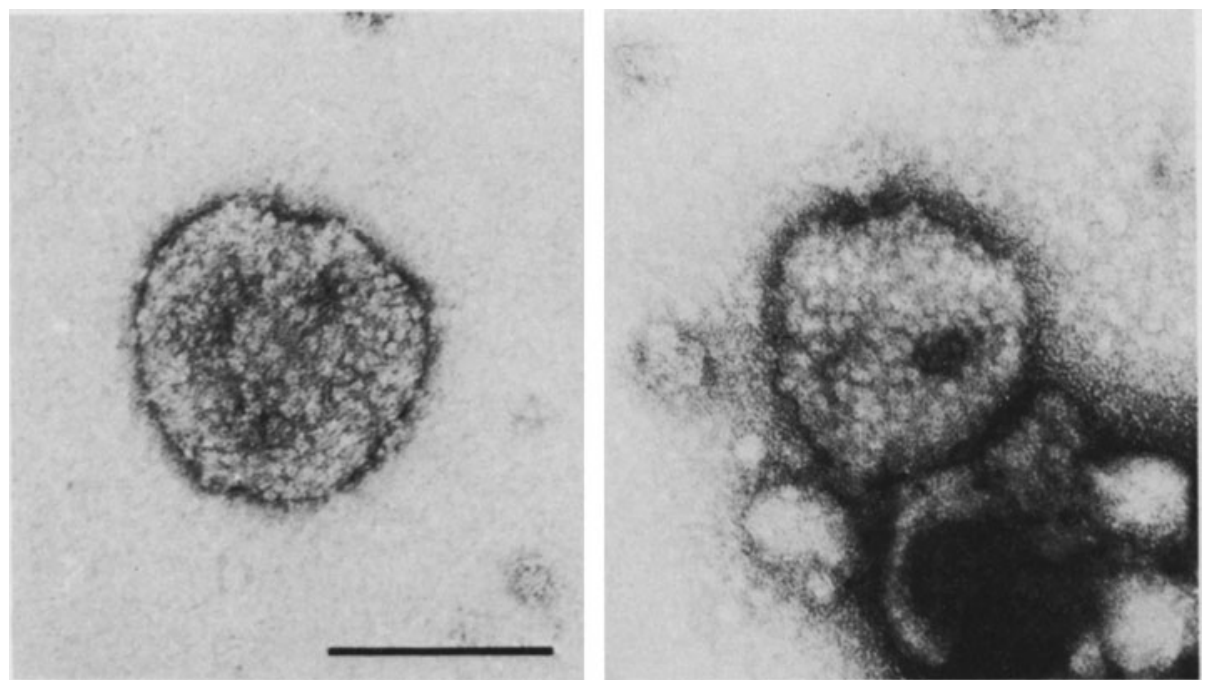

Fig. 1. Bovine leukemia virus particles negatively stained with $1 \%$ uranyl acetate, $\mathrm{pH}$ 4.4, without preceding fixation. Bar: $100 \mathrm{~nm}$ (Electron micrograph provided by F. Weiland)

Several serologically reactive components have been isolated from BLV or from BLV-infected cells. The nomenclature used by the different groups mostly rests on the effect of ether treatment on the serologic activity of antigen preparations although it is whether antigens should be differentiated based solely on reactions with this compound. An 'ether resistant' antigen prepared from a polyethylene glycol-concentrated virus (Miller and Olson, 1972) was reported to be the major internal virus protein. Onuma et al. (1976) isolated a second 'ether sensitive' antigen from cell culture supernatant by affinity chromatography on Con. A Sepharose. The ether sensitive antigen was considered to be a component of the outer virus envelope. Electrophoretic analysis revealed four different polypeptides with relative molecular weights of 55000, 45000, 25000 , and 18000 daltons.

For the present review and for comparative aspects, a nomenclature will be used for BLV proteins to indicate some of the biochemical properties of the individual antigens. Viral proteins and glycoproteins are designated according to their apparent molecular weight (in thousands) as proposed for the structural proteins of oncogenic RNA viruses (August et al., 1974).

Sodium dodecyl sulfate (SDS) electrophoresis on polyacrylamide gels has determined the polypeptide pattern of BLV. Purified Friend mouse (FLV) and feline leukemia (FeLV) viruses were run under the same conditions. After staining with Coomassie brilliant blue, at least seven major and some minor components have been identified in BLV preparations twice purified by sucrose gradient centrifugations (Fig. 1). Proteins p15, p24, and gp69 were purified to electrophoretic homogeneity and were shown to react with specific antibodies from leukemic cattle (Kaaden et al., 1976, 1977; Frenzel et al., 1977; Kaaden, in press). Conclusive proof for the virus specificity of the remaining 
Table 2. Structural proteins of BLV and antigens associated with bovine leukosis

\begin{tabular}{|c|c|c|c|c|c|c|c|c|}
\hline $\begin{array}{l}\text { Pro- } \\
\text { posed } \\
\text { nomen- } \\
\text { clature }\end{array}$ & $\begin{array}{l}\text { Deshayes } \\
\text { et al. } \\
\text { (1977) }\end{array}$ & $\begin{array}{l}\text { Devare } \\
\text { et al. } \\
(1975) \\
\text { Gilden } \\
\text { et al. } \\
(1975) \\
\text { McDonald } \\
\text { and Ferrer } \\
1976 \\
\end{array}$ & $\begin{array}{l}\text { Kaaden } \\
\text { et al. } \\
\text { (1977) } \\
\text { Frenzel } \\
\text { et al. } \\
(1977)\end{array}$ & $\begin{array}{l}\text { Onuma } \\
\text { et al. } \\
(1976)\end{array}$ & $\begin{array}{l}\text { Mol. } \\
\text { wt. } \\
\left(\mathrm{d} \times 10^{-4}\right)\end{array}$ & $\begin{array}{l}\text { Iso- } \\
\text { electric } \\
\text { point }\end{array}$ & $\begin{array}{l}\text { Detected } \\
\text { by }\end{array}$ & $\begin{array}{l}\text { Chemical } \\
\text { nature }\end{array}$ \\
\hline $\mathrm{p} 10$ & p11 & - & pl0 & - & 1.0 & nd & - & Protein \\
\hline p12 & p13 & - & p12 & - & 1.2 & nd & - & Protein \\
\hline p15 & pl6 & - & p15 & $\mathrm{p} 18$ & $1.5-1.8$ & $8.2-8.5$ & ID, CF & Protein \\
\hline p19 & p19 & - & - & - & 1.9 & nd & - & Protein \\
\hline p24 & p24 & $\mathrm{p} 24$ & p21 & p25 & $2.1-2.5$ & $6.2-7.2$ & $\begin{array}{l}\text { CF, ID, } \\
\text { CF, RIA }\end{array}$ & Protein \\
\hline p35 & p35 & - & - & - & 3.5 & nd & $\mathrm{CF}$ & Protein \\
\hline gp45 & - & - & gp45 & gp45 & 4.5 & 5.0 & $\mathrm{CF}$ & $\begin{array}{l}\text { Glyco- } \\
\text { protein }\end{array}$ \\
\hline gp55 & - & - & - & gp55 & 5.5 & nd & ID, CF & $\begin{array}{l}\text { Glyco- } \\
\text { protein }\end{array}$ \\
\hline gp60 & gp60 & - & - & - & - & nd & $\mathrm{CF}$ & $\begin{array}{l}\text { Glyco- } \\
\text { protein }\end{array}$ \\
\hline gp69 & - & - & gp69 & - & $6.8-7.1$ & 5.0 & ID, $\mathrm{CF}$ & $\begin{array}{l}\text { Glyco- } \\
\text { protein }\end{array}$ \\
\hline $\mathrm{p} 80$ & $\mathrm{p} 80$ & - & $\mathrm{p} 80$ & - & $7.8-8.0$ & nd & - & Protein \\
\hline
\end{tabular}

nd $=$ not determined

Reverse transcriptase activity in BLV particles was detected by Dietzschold et al., 1974; Gilden et al., 1975; Kettmann et al., 1975. There are no specifications reported concerning the protein structure of the enzyme

* An p21 antigen was also identified by Paulsen et al. (1976) in both bovine and ovine leukemia viruses by SDS-PAGE and indirect radioimmune precipitation

polypeptides so far has not been obtained. Table 2 contains the current knowledge concerning BLV protein composition. There seems to be consistency for the major internal virus protein p24. Its apparent molecular weight is about 24000 daltons and is most probably identical to the so-called ether-resistant (gs-)antigen (Miller and Olson, 1972; Devare et al., 1976; Gilden et al., 1975; Onuma et al., 1976). Protein p24 can be extracted from BLV particles by treatment with ether, nonionic detergents, or simply by freeze-thawing. It may be purified by isoelectric focusing (Gilden et al., 1975), gel filtration (McDonald and Ferrer, 1976), or SDS acrylamide gel electrophoresis (Gilden et al., 1975; Deshayes, 1977). Precipitating and complement-fixing antibodies against BLV p24 have been detected in sera from leukotic cattle (Miller and Olson, 1972; Gilden et al., 1975; McDonald and Ferrer, 1976; Onuma et al., 1976; Deshayes et al., 1977). Antigen preparations likely to contain BLV p24 showed precipitin lines of identity if reacted in ID tests with sera from leukotic sheep (Paulsen 
et al., 1973). Another basic protein was purified by Kaaden et al. (1976) from sucrose gradient purified BLV particles by affinity chromatography followed by isoelectric focusing and rate zonal sedimentation. It had an apparent molecular weight of 14800 daltons but migrated to a position corresponding to FLV p15 and was therefore designated BLV p15. Specific precipitating antibodies were detected by ID tests in leukotic and BLV-infected animals.

A third structural component of BLV purified to electrophoretic homogeneity was described as BLV gp69 (Frenzel et al., 1977). The glycoprotein isolated by isoelectric focusing and gel filtration showed an isoelectric point of $\mathrm{pH} 5.0$ and an apparent molecular weight in SDS polyacrylamide gel electrophoresis of 69000 daltons. The use of BLV p15, p24, and gp69 as antigens in ID tests resulted in most antibody-positive cattle being detected using gp69 (see Sect. V.B.). No immunologic cross reaction was found between the three isolated virus proteins as far as BLV was concerned, although this was not always the case in murine of FeLV systems. These immunologic studies, which have previously been performed with naturally occurring antibodies, now need to be completed with monospecific antisera.

Comparative electrophoretic analysis of several BLV samples from different sources have shown remarkable differences in the polypeptide pattern. Although there seems to be agreement over BLV proteins lower than molecular weight 30000 daltons, the glycoprotein pattern needs further clarification. As shown in Table 2, at least three additional glycoproteins, besides gp69 have been identified by SDS gel electrophoresis, staining with Schiff's reagent, and complement fixation tests (Onuma et al., 1976; Deshayes et al., 1977). According to the criteria also used for BLV p24, all are suggested to be virus-specific. The question whether virus strain differences, different cell systems, or purification procedures accounts for the discrepancies remains to be answered.

An oncornavirus-specific, RNA-dependent, DNA-polymerase present in leukemic lymphocytes from cattle and also in isolated bovine type $\mathrm{C}$ particles was first described by Kaaden et al. (1972) and Dietzschold et al. (1974). By using the synthetic templates poly $(\mathrm{rA}) \cdot \operatorname{poly}(\mathrm{dT})$, poly $(\mathrm{rA}) \cdot \operatorname{oligo}(\mathrm{dT})_{10}$, and poly $(\mathrm{dA}) \cdot \operatorname{poly}(\mathrm{dT})$ these authors were able to differentiate between the oncornavirus-specific and similar enzymes of cellular origin. The enzyme associated with the type $\mathrm{C}$ particle fraction responded very well to poly $(\mathrm{rA}) \cdot \mathrm{oligo}(\mathrm{dT})_{10}$, whereas poly $(\mathrm{dA}) \cdot \operatorname{poly}(\mathrm{dT})$ exhibited a poor template activity. The virus particle enzyme most specifically, was capable of using heterologous 70S RNA from FLV as a template. These findings suggest that the bovine leukemia virus particle enzyme can be classified as an oncornavirus-specific DNA polymerase. The findings were confirmed by Gilden et al. (1975); and Kettmann et al. (1975). Contrary to typical mammalian oncornaviruses, BLV polymerase, like that from mouse mammary tumor and endogenous feline RD114 viruses, showed a higher activity in the presence of magnesium ions, whereas in the presence of manganese, a lower activity was recorded. The preference of magnesium ions for DNA-polymerase activity was considered an additional differentiating factor of BLV from typical mammalian oncornaviruses. Definitive proof that BLV is indeed an oncornavirus was obtained by Kettmann et al. (1975). About $85 \%$ of labelled complementary DNA synthesized in vitro by the high molecular 
weight RNA-reverse transcriptase complex hybridized to BLV RNA. The 'back' hybridization of in vitro synthesized CDNA to RNA complements other characteristics of the BLV reverse transcriptase and provides the biochemical evidence to classify BLV as an oncornavirus. The BLV DNA-polymerase molecular weight as well as its possible immunologic relationship to other oncornaviruses remain to be established.

\section{B. Morphology}

The morphogenesis of BLV has been studied in detail during recent years by electron microscopy. Using the ultrathin sectioning technique, BLV particles were found to be almost spherical with an electron-dense nucleoid surrounded by an outer envelope that consisted of a double layered membrane (Miller et al., 1969; Stock and Ferrer, 1972; Weiland et al., 1974; van der Maaten et al., 1974; Calafat et al., 1974). Projections on the surface of the particles could be detected occasionally. The bovine type $\mathrm{C}$ particles described in short- or long-term cultures of leukemic leukocytes were $90-110 \mathrm{~nm}$ in diameter with a centrally located dense nucleoid of about 60-80 nm (Miller et al., 1969; Ferrer et al., 1971; Weiland et al., 1974; Calafat et al., 1974). An additional intermediate membrane covering the nucleoid was seen in single cases. In general, bovine type $C$ particles budding from the cellular plasma membranes or cytoplasmic vesicles was only rarely observed. The budding process, which terminated with the release of type $C$ particles, mostly occurred earlier than $24 \mathrm{~h}$ after the initiation of cultures and was described as exhibiting some peculiarities not found in murine or rat oncornavirus-infected cells (van der Maaten et al., 1974; Calafat et al., 1974). Typical mammalian oncornavirus development is characterized by the release of immature type $\mathrm{C}$ particles with an electron-lucent core bordered by a double-layered core shell, which was not, however, consistently observed. Later condensation of this core shell into nucleoids was found to result in the formation of mature $C$ particles (Gelderblom et al., 1972). In several aspects, however, BLV appears different; the virus was described as budding off the plasma membrane as mature enveloped $\mathrm{C}$ particles with an electron-dense, central nucleoid, with no immature $\mathrm{C}$ particles found independent of the cell (Calafat et al., 1974). Controversial findings on the morphologic appearance of BLV were reported by Weiland and Ueberschär (1976). By comparison with murine and feline oncornaviruses, these authors did not observe any uncommon budding BLV particles.

In negatively stained preparations of isolated virions, the outer envelope of BLV particles was found to show knob-like surface projections of about $8 \mathrm{~nm}$ (Fig. 2), which were similar to murine and feline oncornaviruses. The outer sac-like envelope had a diameter of $120-150 \mathrm{~nm}$ and was found to be very labile, thus displaying the internal core structure. The virus core seemed to be arranged in morphologic subunits of hexagonal shape. After treatment with a nonionic detergent followed by freeze-drying and shadowing with carbonplatinum the hexagonal arrangement of the core structure often became more visible (Weiland et al., 1974; Weiland and Ueberschär, 1976). 


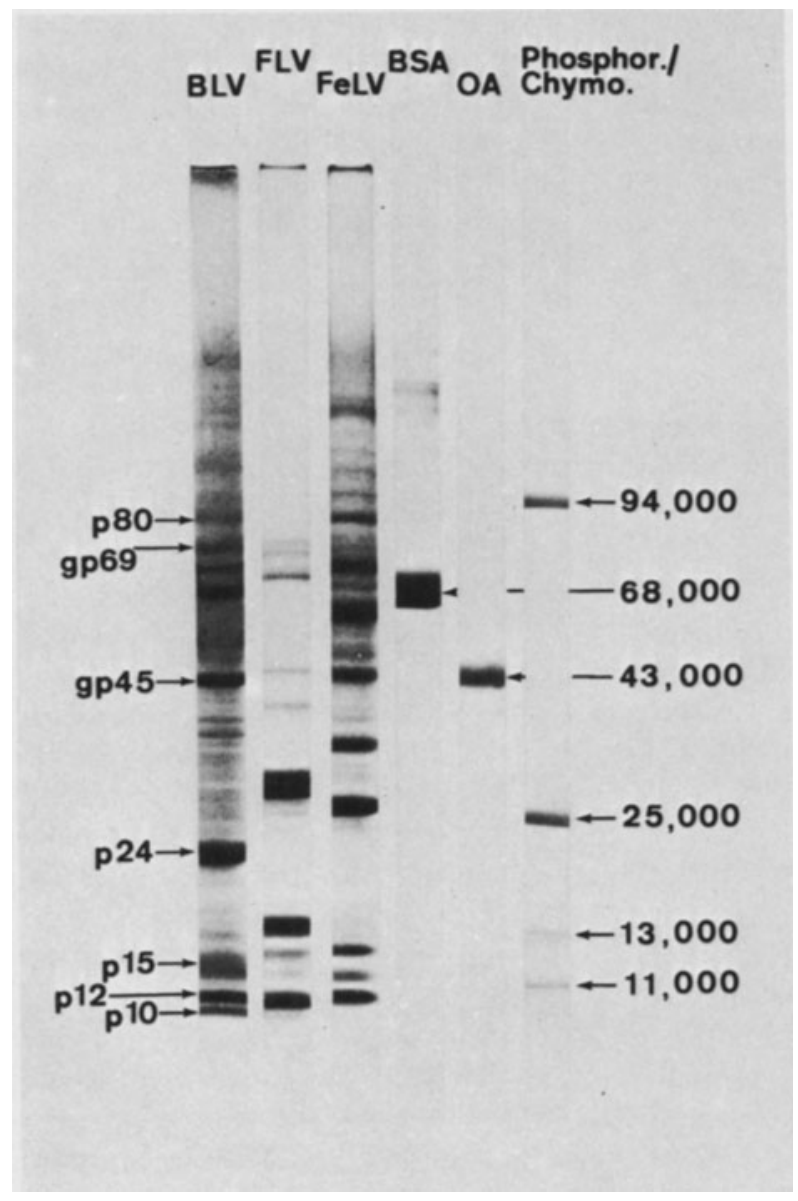

Fig. 2. Sodium dodecyl sulfate $(S D S)$ electrophoresis of bovine leukemia $(B L V)$, Friend mouse leukemia $(F L V)$ and feline leukemia $(F e L V)$ viruses on a polyacrylamide slab gel. The marker proteins used were bovine serum albumin $(B S A)$, ovalbumin $(O A)$, chymotrypsinogen (Chymo.) and phosphorylase a (Phosphor.). The slab gel was prepared from a $7.5 \%-20 \%(\mathrm{w} / \mathrm{v})$ acrylamide gradient and a $3 \%$ stacker gel. The electrophoresis was run at $18 \mathrm{~mA}$ and $60 \mathrm{~V}$ for $6 \mathrm{~h}$

\section{Genetic Relatedness to Host DNA}

RNA tumor viruses have been classified into two classes based on molecular hybridization experiments. Class 1 (endogenous) consists of viruses whose RNA genome was found to be closely related to progenitor cells (genetic relatedness $\geqq 75 \%$ ) if hybridized to an excess of cellular DNA. Class 2 (exogenous) RNA tumor viruses consisted of other tumor, viruses whose RNA genome interacted only to a limited extent $(15 \%-30 \%)$ with cellular progenitor DNA (Gillespie and Gallo, 1975). To clarify the situation with regard to bovine leukosis, the 
problem of molecular events associated with virus replication mechanisms and the possible integration of viral nucleic acid into the cellular DNA genome needed resolving. Molecular hybridization studies using BLV-complementary DNA as a probe strongly suggested that BLV-specific cDNA could not be detected in normal bovine cells (Callahan et al., 1976). In controlled experiments, about $60 \%$ of the radioactive cDNA annealed with bovine DNA from leukemic cells (Kettmann et al., 1976), thus demonstrating the exogenous nature of the virus. Taking into account the findings from these molecular hybridization experiments together with those from transmission experiments and epizootiologic observations, bovine leukosis is inferred to be an infectious disease caused by an exogenous RNA tumor virus.

\section{Host Spectrum}

Transmission experiments with cell-free BLV together with epizootiologic observations provided cumulative evidence that bovine leukosis can be experimentally induced in cattle (see Sect. II.C.4). Sufficient evidence is also available that tumor material from leukemic cattle, as well as isolated BLV from cultivated cells, is capable of inducing lymphocytosis and/or lymphosarcomas in sheep (Wittmann and Urbaneck, 1969; Mammerickx, 1973; Olson et al., 1972; 1976). Sheep were found to be easily handled experimental animals which were also amenable to infection by oral transmission. Furthermore, on reisolation from experimentally infected sheep, BLV maintained its pathogenicity for cattle. Hoss and Olson (1974) demonstrated that BLV infection could also be established in goats in a similar manner to that established in sheep. The possible role of game as a natural virus reservoir remains to be investigated.

In numerous experiments, leukotic material from cattle has been inoculated into rabbits, guinea pigs, and mice (see review Wittmann and Urbaneck, 1969). Tumors which appeared in inoculated mice could not be attributed clearly to the bovine leukosis agent (Straub, 1965) because spontaneous neoplasia also occurred in control groups with remarkable frequency. More sophisticated virologic and immunologic techniques, however, have not yet been intensively employed in following experimental infections. Athymic (nude) mice after irradiation with ${ }^{60} \mathrm{Co}$ tolerated the implantation of leukemic lymphocytes and developed isolated transplantable tumors. Chromosome analysis of the tumor cells, however, revealed that they still showed the normal diploid bovine but not murine karyotype (Irvin et al., 1977). The malignancies, therefore, have to be considered as bovine leukosis tumor transplants in mice but not as a genuine BLV-induced murine neoplasia. Sprague-Dawley rats that were experimentally inoculated with cellfree BLV or leukemic lymphocytes developed neither tumors nor specific antibodies (Barthold et al., 1976). The potential human health hazards arising from the consumption of milk and meat obtained from BLV-infected or leukemic cattle have long been taken into consideration. Serologic examination of sera from BLV-exposed individuals, e.g., laboratory personnel, veterinarians and farmers, have never revealed specific BLV-antibodies (Gilden et al., 1975; Olson, 1974). Experiments performed at the University of Wisconsin additionally demonstrated that commercial pasteurization destroyed BLV infectivity. 
After heating at $74^{\circ} \mathrm{C}$ for 16 seconds, BLV in experimentally contaminated milk completely lost its infectivity for inoculated lambs. On the other hand, chimpanzees inoculated with BLV showed a serologic response to virus antigens between 6 and 15 weeks post inoculation (van der Maaten and Miller, 1976). Even though there was no proof that BLV replicated in circulating lymphocytes of the chimpanzees, the detection of humoral antibodies as well as the in vitro infection of human embryonic lung and skin cells (Graves and Ferrer, 1976) may indicate a certain interaction between BLV and primate host cells.

\section{E. Relationship to other Retroviridae}

Mammalian oncornaviruses from the mouse, rat, cat, gibbon ape, and woolly monkey are more or less related based on homologies of virus RNA to cDNA as found by RNA-DNA cross hybridization studies (see review Hehlmann, 1976). Many RNA tumor viruses also share common antigenic determinants which, in some cases, have also been verified by analysing the primary structures (see review Gilden, 1975). The antigenic interrelationships between some structural proteins are expressed as group-specific (p10, p15, p30) and interspeciesspecific (p30, gp69/71) determinants whereas others only carry type-specific antigenic sites (p12). Efforts to demonstrate a genetic or antigenic relationship of BLV to other members of the family Retroviridae generally produced negative results. The first series of these experiments, designed by Ferrer, (1972) showed that BLV antibodies did not react with murine and feline leukemia-sarcoma virus antigens if tested in ID and immunofluorescence (IFA) tests. The studies, later extended by $\mathrm{CF}$ tests and radioimmunoassay (RIA) revealed no serologic relationship between $\mathrm{BLV}$ and oncornaviruses to include type $\mathrm{B}$ oncornaviruses (Gilden et al., 1975; McDonald and Ferrer, 1976; Kaaden et al., 1977). BLV also lacked any immunologic reactivity with antisera against such widely distributed bovine agents as foamy-like bovine syncytial virus (BSV), parainfluenza-3, infectious bovine rhinotracheitis (IBR), bovine virus diarrhea (BVD), and maedi-like BSV (R-29) (Diglio and Ferrer, 1976; Graves and Ferrer, 1976). The only serologic relationship described so far was detected between BLV and ovine leukemia viruses. Antigen preparations, probably containing BLV p24, produced reactions of complete identity when tested with bovine or ovine sera against leukemia viruses (Paulsen et al., 1973; 1974).

Furthermore, it was demonstrated that antibodies against bovine leukemia viruses exhibited reciprocal syncytial blocking properties suggesting that the viruses were closely related (Ogura et al., 1977).

It remains to be shown by structural analysis of the virus proteins and molecular hybridization studies that ovine leukemia virus is indeed a genuine agent of sheep and not BLV transmitted to a heterologous host. Hybridization studies so far performed with reverse transcripts of the RNA BLV genome as well as with ${ }^{125}$ I-labeled BLV-RNA were fully consistent with the negative results concerning the antigenic cross-reactions. This also suggests a lack of genetic relationship to any other RNA tumor virus (Callahan et al., 1976; Kettmann et al., 1976). Therefore, BLV may be assumed to represent a group of its own within the family Retroviridae. 


\section{Serologic Diagnosis}

Until recently, diagnosis of enzootic bovine leukosis relied on the demonstration of lymphosarcoma and/or repeated examination of the blood to detect a persistent lymphocytosis. In countries where systematic control programs have been initiated, repeated examinations of peripheral blood are performed. They are evaluated by "leukosis keys" that are based on determination of the total number of leukocytes per $\mathrm{mm}^{3}$ and differential counting of the leukocytes. The keys usually divide the results into three groups: normal, suspicious, and leukemic (positive). Recently, workers of the nine member states (Straubet al., 1977) established a "European Community Key".

When serologic methods of demonstrating antibodies to bovine type $\mathrm{C}$ particles were developed, their sensitivity and specificity was determined by comparing the serologic results with hematologic examination, detecting bovine $\mathrm{C}$ type particles in corresponding lymphocyte cultures, and/or determining origin of the animals from leukotic herds.

\section{A. Agar Gel Immunodiffusion}

Miller and Olsen (1972) demonstrated the presence of a precipitating antigen in preparations of bovine type $C$ particles obtained from both mitogen-stimulated and nonstimulated lymphocyte cultures and detected antibodies against this antigen in leukotic cattle sera. Experiments have been carried out to elaborate antigen preparations suitable for the agar gel ID test and the characterization and use of such antigens. Survey investigations have been done to determine the sensitivity and specificity of the ID test as a serologic tool to diagnose enzootic bovine leukosis and experiments to follow up the appearance of precipitating antibodies in BLV-infected animals.

Besides stimulated lymphocyte cultures, FLS or FLK monolayer cultures replicating BLV (van der Maaten et al., 1974) have served as viral antigen sources. Other cell lines (see Section III.C.2) have also been used in some instances. Several techniques have been applied to prepare for precipitating antigens and these have often resulted in preparations differing in their antigenic composition. Basically, the following antigen preparations can be distinguished:

a) The original method described by Miller and Olson (1972) which consisted of the BLV concentration followed by ether treatment. Such a preparation can be assumed to contain all components of BLV although some of these components may have lost their serologic activity from the ether treatment. Such an antigen derived from BLV-producing cell lines is designated in the present review as "ether-treated antigen."

As mentioned earlier (Section IV.A.), Gilden et al. (1975), McDonald et al. (1976) and Onuma et al. (1976) partially purified a protein (p24) with a molecular weight of 24,25 , and 23 kilodaltons, respectively, from BLV preparations or from extracts of infected cells. In the ID test, this protein was shown to give a line of identity with the ether-treated antigen (McDonald and Ferrer, 1976). However, this is not reason enough to term the above-mentioned ether-treated 
antigen as p24- or gs-antigen; at least the designation 'p24-antigen' should be restricted to highly or partially purified BLV p24 preparations. We use the term p24-antigen in this sense.

b) After removal of BLV particles by ultracentrifugation, two antigens were detected in the concentrated supernatant of BLV-infected cultures by use of the ID test (Onuma et al., 1975). One was a component of the ether-treated antigen, the other was described as ether-sensitive. This latter antigen was later described as consisting of a major component (45000 daltons) and three minor components (55000, 25000 and 18000 daltons) after isolation by Con. A (Onuma et al., 1976). The ether sensitivity of this antigen was demonstrated by a rather rigorous method; the preparation was mixed with 10 volumes of ether and then agitated occasionally at room temperature until the ether evaporated. A method to prepare a "dual antigen" containing unpurified p24 and glycoprotein(s) of BLV was described by Miller and van der Maaten (1976). This antigen preparation is comparable with the above mentioned nonseparated supernatant antigen (sup-prep) of Onuma et al. (1975). Here we refer to these two antigen preparations by the term "concentrated supernatant antigen".

c) Preparations containing all antigenic BLV components can be obtained from concentrated BLV by freezing and thawing (Frenzel, personal communication). Such preparations are termed "disrupted BLV antigen".

d) Frenzel et al. (1977) succeeded in isolating and purifying a glycoprotein (gp69) from purified BLV; Kaaden et al. (1977) reported isolating and purifying a p15 protein; Kaaden (unpublished results) also prepared a purified p24 protein. These purified BLV components are designated in the present report as "p15-", "p24-", and "gp69"-antigen.

The composition of the agar used in the ID test varied among different laboratories. The test was frequently performed according to the Miller and Olson (1972) method with $0.8 \%$ agarose prepared in $0.05 \mathrm{M}$ tris buffer, $\mathrm{pH}$ 7.2 , containing $8.5 \% \mathrm{NaCl}$, and filling the wells only once. Others used $1.5 \%$ agarose containing 9\% $\mathrm{NaCl}$ (Flensburg and Streyffert, 1977), 0.8\% agarose and $7 \% \mathrm{NaCl}$ (Gilden et al., 1975), $0.7 \%$ agarose containing $8.5 \% \mathrm{NaCl}$ (Ressang et al., 1976a), also borate buffer, pH 8.3, was used instead of tris buffer (Paulsen et al., 1975), and procedures employing $2 \%$ agar and filling the wells twice have also been described (Ferrer et al., 1974).

Using the ether-treated antigen Olson et al. (1973) tested approximately 1000 dairy cattle in 11 herds for the presence of precipitating antibodies. In this study, 222 reactors were detected. Five herds in which lymphosarcoma had not occurred during the past 13-33 years had a lower percentage of reactors $(2 \%-16 \%)$ than six herds with 21 cases of lymphosarcoma in the last seven years $(24 \%-42 \%$ reactors $)$. BLV was demonstrated by in vitro cultivation in 100 to 117 reactors including cattle in the five herds with no lymphosarcoma. These results showed a good correlation between detecting precipitating BLV antibodies and demonstrating virus.

The value of the ID test to diagnose enzootic bovine leukosis was further demonstrated by several authors. Olson and Baumgartener (1975) tested 97 cattle sera from Denmark. Whereas antibodies were found in 19 sera from herds with multiple cases of lymphosarcoma or cases of persistent lymphocytosis, 
sera from 32 cattle in leukotic-free herds were negative. Ferrer et al. (1974) reported that precipitating antibodies to a BLV ether treated antigen are frequent in multiple- and single-case herds; 259 serum samples from such herds were examined by ID test and 105 were found positive. An interesting finding was that 148 of these samples were taken from animals without persistent lymphocytosis but 23 of them reacted positively to the ID test.

Five herds affected with enzootic bovine leukosis were screened by Mammerickx et al. (1976). Agreement between hematologic and ID tests was found in 219 cases; 15 animals were seropositive but hematologically negative. These results indicate that serologic examination is a suitable method for early diagnosis of enzootic bovine leukosis. This conclusion was also reached by Ressang et al. (1976a) who examined 516 animals from six herds using the ID test; 20 of these animals had lymphocytosis and 44 had precipitating antibodies. Ferrer et al. (1974) as well as Ressang et al. (1976a) found a good correlation between presence of antibodies and BLV detection, either by electron microscopy or cocultivation; therefore animals with antibodies to BLV can be assumed to be potential BLV carriers.

The observation has been made repeatedly that in leukotic herds, nearly all hematologically positive animals are found to be seropositive with the ID test and further, that in such herds, the ID test reveals even more positive reactors in comparison with hematological examination. Paulsen et al. (1973) examined 88 cattle in a milk herd with leukosis; 23 of 25 hematologically positive animals, and 12 of 63 cows with normal lymphocyte counts had precipitating antibodies against the ether-treated antigen. Later Paulsen et al. (1975, 1977) tested 2586 cattle from 280 individual herds. In herds with leukosis, most of the hematologically positive animals also reacted positively to the ID test; among the hematologically normal animals $13 \%$ in one herd and $45 \%$ in another were positive in the ID test. Out of a total of 1860 animals from 255 herds classified free of leukosis, only $0.8 \%$ gave positive serologic reactions. In a pilot study performed by Chander (1976), the ID test with the ether-treated antigen gave more positives than examination for lymphocytosis. Flensburg and Streyffert (1977), and Robertson et al. (1977), also working with ether-treated antigen found a significant agreement between the hematologic and the serologic tests. Using the "BLV disrupted antigen", Frenzel et al. (1976) tested 368 sera from different farms with the ether-treated antigen, 68 of which were obtained from hematologically positive animals. In the ID test, $51.4 \%$ were found to be positive, while $23.4 \%$ gave no definite reaction. From 55 hematologically suspect animals, $48.5 \%$ were positive while $9 \%$ of sera gave equivocal results. Among 245 hematologically negative animals the figures were $1.6 \%$ and $2 \%$, respectively. Additionally, Frenzel et al. (1977) tested 35 sera from hematologically positive animals from six farms using the gp69 antigen. Thirty-four sera were positive in the ID test, whereas 197 sera from animals with normal lymphocyte numbers from 98 farms that were free of bovine leukosis all gave negative reactions with this antigen. Mitscherlich et al. (1976) tested 75 blood samples from high incidence herds hematologically as well as for the presence of BLV antigen and antibodies (ether-treated antigen at $4^{\circ}$ ). In $87 \%$ of the animals, antigen was detected, $60 \%$ were antibody positive and $49 \%$ were classified 
as hematologically positive. An interesting observation was that in 482 samples from herds with a long history of leukosis and participating in an eradication program, only 3 were hematologically positive, but in 19 samples antibodies were detected. This was explained by an increase of the relative rate of aleukemic tumorous forms after the eradication of animals with persistent lymphocytosis, together with their offspring. This may indicate that aleukemic forms can be detected with the ID test. Indeed, Albrecht et al. (1976) detected precipitating antibodies in postmortem organ extracts or blood from organs and tumor specimens obtained from animals which had suffered from aleukemic lymphosarcoma; in 21 out of 24 cases leukosis-specific antibodies were found.

Miller and van der Maaten (1976) compared the ether-treated antigen with the concentrated supernatant antigen using 117 cattle sera. With the concentrated supernatant antigen, $88 \%$ of the sera were found positive, whereas only $55 \%$ gave a positive reaction with the ether-treated antigen. Straub (1977) studied 657 cattle from three dairy farms. All 38 hematologically positive animals had positive ID test results. No cases where only antibodies against the ether-treated antigen and none against an antigen preparation containing concentrated tissue culture fluid from BLV-infected cells were detected. However, from 57 serum samples reacting positively with this antigen, only 39 were positive with the ether-treated antigen. A similar experience was made by Onuma et al. (1975). Frenzel (personal communication) compared four antigen preparations derived from a BLV producing cell line: (1) a preparation containing BLV disrupted by freezing and thawing, (2) a purified p24 preparation, (3) purified gp69, and (4) purified p15. Fifty-nine sera reacted with both the gp69 antigen and the disrupted BLV antigen; nine with the p15-antigen; and only one with the p24-antigen. The latter result was unexpected and requires additional experimentations. The observation that antigen preparations containing BLV-glycoprotein(s) are superior to the ether-treated antigen in detecting BLV-specific antibodies should have consequences in preparing antigens to be applied in field testing programs. It may also explain why some authors working with ether-treated antigen have questioned the sensitivity of the ID test in detecting BLV-specific antibodies (Straub et al., 1974; Ferrer et al., 1975). The relatively few exceptions in which the serum of hematologically positive animals or animals with lymphosarcomas reacted negatively in the ID test may be due to the use of the ether-treated antigen. Olson and Baumgartener (1975) reported two cattle with lymphosarcoma and two cattle with persistent lymphocytosis, which were found seronegative. Mammerickx et al. (1976) could not detect precipitating antibodies in 11 hematologically positive animals, and in another study (Paulsen, 1977) only 42 serum samples out of 162 from hematologically positive animals were found positive. Flensburg and Streyffert (1977) also detected leukotic herd three hematologically positive animals with a negative ID test.

Few serologically positive animals have been found in herds with no history of enzootic bovine leukosis. Ferrer et al. (1974) reported four seropositive animals out of 244 tested, and Paulsen et al. (1977) found two seropositive animals among 359 from 56 herds. It could not be decided whether these animals were indeed false positive reactors or whether they were indicators for recent introduction of the disease into a herd that was, until then, free of leukosis. 
It was noticed in these various serological surveys that very few serum samples from cattle less than two years old were found to react in the ID test. Olson and Baumgartener (1975) and Baumgartener et al. (1975) suggested that this indicated a slow development of the virus infection. In experimental infections of new-born calves with large infective doses, both antibody and virus could be demonstrated in three to four months (Miller et al., 1972). Additional follow-up studies with naturally infected animals are therefore necessary to gain more information about the development and persistence of BLV-specific antibodies, the classes of antibody produced, and their specificity for the major BLV components.

Sera from animals with calf and thymic form of lymphosarcoma as well as from the skin type of infection did not contain antibodies detectable by the ID or other serologic tests to be discussed later (Miller et al., 1972; Olson and Baumgartener, 1976; Onuma et al., 1975; Albrecht et al., 1976). Curiously enough, however, tumor tissues from animals with juvenile forms can induce virus infection in experimental calves and sheep (Miller et al., 1972).

It was demonstrated that 13 out of 14 sera from sheep with spontaneous lymphatic leukosis showed precipitin reaction with an BLV ether-treated antigen (Paulsen et al., 1974). The development of precipitating antibodies was investigated after the infection of lambs with BLV lymphocyte cultures (Hoss and Olson, 1974) or pooled whole blood from cattle with persistent lymphocytosis as done by Ressang et al. (1976b) who infected goats as well as sheep. Antibodies could be detected as early as one to three months (goats), and four to seven months (sheep) after infection.

\section{B. Complement-Fixation}

Miller and van der Maaten (1974) and Miller et al. (1974) developed a complement-fixation (CF) test by which BLV-specific antibodies could be detected. Clarified tissue culture fluids from BLV-producing cell lines were used as the antigen which could be concentrated by dialysis against polyethylene glycol and treated with Triton X-100 (Paulsen et al., 1977). In comparing results obtained with the ID and the CF tests, one should be aware that the antigen preparations applied in the latter contain all components of BLV in contrast to the majority of the antigen preparations used in the ID test (Sect. V.A). The CF test is frequently performed in a microtiter system, and the guinea pig complement system is supplemented with an appropriate cattle serum. Miller and van der Maaten (1974) using ether-treated antigen tested 52 sera from cattle with lymphosarcoma and detected complement-fixing antibodies in 47 and precipitating antibodies in 46. Onuma et al. (1975) found 11 out of 13 sera positive from cattle with naturally occurring lymphosarcoma in the CF test (one serum was anticomplementary). This agreed with results the ID test performed with a concentrated supernatant antigen. There was also a good agreement between CF and ID tests in the studies of Ressang et al. (1976a) who examined 516 sera and detected antibodies with the ID test ("ether-treated antigen") in 44 and with the CF test in 47 samples. Chander (1976) concluded that the ID test gave more positive results than the hematologic examination, 
and the CF test more than the ID test. These observations were supported by investigations of Paulsen et al. (1977) who reported the following results: 89 serum samples from a high incidence herd were tested; all 34 samples from animals with persistent lymphocytosis were positive in the CF and ID tests. Among the 55 samples from hematologically negative animals, 46 were found sero-positive in the CF test, but only seven sero-positive in the ID test. These tests were performed using the ether-treated antigen. In addition, 1352 serum samples that collected from leukotic herds were investigated; among 162 samples from animals with persistent lymphocytosis, 143 and 114 were positive in the $\mathrm{CF}$ and the ID tests, respectively. In the group of 74 sera from hematologically suspect animals, 41 were found positive in the CF test and 30 in the ID test. From the remaining 1116 samples from hematologically negative animals, 295 reacted positively in the $\mathrm{CF}$ test and 62 in the ID test. Twenty-three animals were unexpectedly CF-positive out of 390 cattle from 56 herds with no history of bovine leukosis; only two of these animals were found positive by the ID test ("ether-treated antigen"). No complement-fixing antibodies to BLV were detected by Tabel et al. (1976) in a herd free of leukosis. Eight bleedings at monthly intervals were done on 22 animals in this herd. By comparison, the cattle of a leukosis herd were tested over an 18-month period and persistent serum antibodies to BLV were demonstrated by the CF test. Parodi et al. (1976) also observed no positive CF-reaction with 48 sera from leukotic free herds, but among 298 sera from leukotic herds, 109 were positive in the CF test. Fifty-four of these positive sera were obtained from animals with normal lymphocyte counts. Levy et al. (1976) carried out CF tests with 224 sera from animals belonging to a mixture of 12 multiple- and single-case herds. Forty-seven out of 74 sera from animals with persistent lymphocytosis or with a suspect lymphocyte counts, and 40 out of 150 sera from hematologically negative animals were sero-positive. Thirty-eight sera from leukemia free herds were tested and found negative in the CF test.

From these results one may conclude that the CF test is more sensitive in detecting BLV specific antibodies than the ID test; however, it should be noted that in most studies in which both tests have been compared, an ethertreated antigen and not the more sensitive gp or concentrated supernatant antigen was used in the ID test. With antigens containing BLV glycoprotein(s) the superiority of the $\mathrm{CF}$ test may have been less evident. It remains to be determined whether in both CF and ID tests, the same antibodies are involved and, further, which of the BLV components induce and react with complementfixing antibodies. Before definitive statements can be made we need to know if the CF antigens are the same as those reacting in the ID test. Further information is also required about the percentage of anticomplementary sera, which have to be disregarded for the CF test, and also about the possibility of false positive reactions.

\section{Immunofluorescence}

The IFA technique has been employed to demonstrate BLV-specific antigens in tumor tissues, short-term buffy-coat cultures established from cows with leukemia, cultured cells producing bovine type $\mathrm{C}$ particles, and to demonstrate BLV-specific antibodies. 
Gillette et al. (1969) examined tumor tissues from cattle with naturally occurring lymphosarcoma using fluorescein isothiocyanate-conjugated antitumor cell sera produced in calves. These sera stained homologous tumor cells from cattle used for immunization. The staining was observed only in the cytoplasm and was generally diffusely distributed. An antiserum prepared against tumor cells from two donor cattle had a broad range of reactivity and stained tumor cells from six of nine other cattle. In cell lines derived from leukotic cows (NBC cell lines) and in short-term buffy-coat cultures of a cow with persistent lymphocytosis, a proportion of the cells showed a brilliant cytoplasmic fluorescence when tested by the direct or indirect immunofluorescence method with serum from a cow in which leukemia had regressed spontaneously (Ferrer et al., 1972). The already-mentioned cell cultures of human, simian, bovine, canine, caprine, ovine, and bat origin, cocultivated with BLV-infected cells or inoculated with cell-free BLV preparations were shown to contain cells in which antigen could be detected by the indirect IFA test using a serum from a leukotic cow (Graves and Ferrer, 1976). A similar observation was made by Ressang et al. (1974) in one bovine and two sheep cell lines which continuously produced bovine type $\mathrm{C}$ particles.

BLV-producing cell lines have been used to detect BLV-specific antibodies by the indirect IFA. In multiple case herds, Ferrer et al. (1974) found positive results in $90 \%$ of leukemic animals by this method. Clinically normal cattle with persistent lymphocytosis in the multiple case herds had a similar incidence $(80 \%-100 \%)$ of antibody, but the titers were generally lower than in the leukemic group. Cattle with normal lymphocyte counts in the multiple case herds also had BLV antibodies; in each of these herds, however, the groups of normal animals had lower incidences and usually lower titers than the corresponding groups with persistent lymphocytosis. In a single case herd, in which one animal out of 54 had a persistent lymphocytosis, sera were collected for three years before leukemia occurred. Eighteen animals had antibodies and most of these were of low titer. The specificity of the IFA test was demonstrated by the usual controls and by the fact that virus was found by electron microscopy in $90 \%$ of cattle with positive reactions. In contrast, virus was not seen in antibody-negative animals (Ferrer et al., 1975). In the investigations of Ressang et al. (1976a) serum samples from 516 animals, fluorescent antibodies to BLV were detected in 67 seras and precipitating antibodies in 44 indicating a higher sensitivity of the indirect IFA technique. Frenzel et al. (1976) confirmed this in a study with sera from 368 cattle, which also demonstrated that an anticomplement immunofluorescence (ACIF) test was superior in sensitivity to the indirect technique. The ACIF test was performed with human complement and fluorescence-conjugated antihuman complement $C_{3}$ (Frenzel et al., 1975). From 68 hematologically positive animals, $92.6 \%$ were found positive in ACIF, $70.6 \%$ in the indirect IFA test, and $51.4 \%$ in the ID test. The corresponding figures for sera from 245 hematologically negative animals were $30.5 \%, 14.5 \%$, and $9.0 \%$.

The fluorescent antibodies were removed by absorption with BLV ethertreated antigens (Ferrer et al., 1976). Absorption of ACIF-positive bovine leukosis antiserum with BLV-p15 resulted in a reduced fluorescence, whereas after absorption with BLV antigens obtained by affinity chromatography, the serum was completely negative in the ACIF test (Frenzel et al., 1976). These results 
indicate that several antigens are detected by immunofluorescence in the cytoplasm of BLV-producing cells.

The conclusion from these results is that immunofluorescence is a specific and sensitive method to detect BLV antibodies. However, the test is laborious and the examination of hundreds of specimens under the fluorescence microscope is tiresome. Therefore, the test seems not to be practical for routine work (Mussgay and Kaaden, 1976), though useful for special examinations.

\section{Radioimmunoassay}

Radioimmunoassay (RIA) for BLV has been applied to detect serologic reactivity against BLV. McDonald and Ferrer (1976) purified the p24 BLV protein by gel filtration and affinity chromatography and the protein was labeled by the chloramine- $T$ method. Comparing the relative sensitivities of the double antibody precipitation RIA, indirect IFA technique, and ID test (ether-treated antigen) revealed that the titers in the radioimmunoassay were much higher than those obtained in the indirect IFA test. Furthermore, only one of six sera with titers of $1: 1024-1: 4096$ in the RIA and 1:2-1:8 in the indirect fluorescent antibody test was positive in the ID test. Twenty sera from cattle in multiple case herds that were positive in the indirect IFA test, and 36 samples from cattle in leukemia-free herds that were negative in this test were assayed at dilutions 1:50, 1:100, and 1:1000 for binding activity. All sera positive in the indirect IFA test bound $80 \%$ or more of the labeled protein at each dilution tested. In contrast, even at a dilution of $1: 50$, all sera from cattle in leukemia-free herds were either completely negative or precipitated less than $5 \%$ of the antigen. A competitive assay using the labeled p24 protein and either bovine reference BLV serum or rabbit anti-p24-BLV serum permitted the detection of nanogram antigen quantities in extracts of BLV-infected bovine lymphoid cells or BLVinfected bat cells. Devare et al. (1976) performed RIA with p24-BLV purified by phosphocellulose ion exchange chromatography and labeled with ${ }^{125} \mathrm{I}$ by the chloramine-T method. They also used the double antibody technique. Sera obtained from 25 cases of adult bovine lymphosarcoma were serologically reactive against BLV-p24. About half of these sera had titers greater than 1:10000. In a high incidence leukosis herd, 17 of 20 sera from cattle reacted with p24-BLV; the titers varied from $1: 40$ to $1: 16000$. In contrast, none of the 15 sera from a minimal disease herd showed detectable reactivity against BLV.

RIA is unquestionably the most sensitive method to detect BLV antibodies. However, more work needs to be done to decide whether the assay should performed with ${ }^{125} \mathrm{I}-\mathrm{BLV}-\mathrm{p} 24$ or eventually with the ${ }^{125} \mathrm{I}-\mathrm{BLV}$-gp69. More surveys with a large number of animals are necessary to determine how often false positive reactions may occur. Also, techniques should be developed which minimize work and material, which would then allow RIA to be applied for routine diagnosis of enzootic bovine leukosis.

\section{E. Indirect Immunoperoxidase Test}

This test makes use of antibodies labeled with horseradish peroxidase enzyme. In the indirect test as applied by Ressang et al. (1976a) to detect anti-BLV 
antibodies, cultured BLV cells were covered with dilutions of sera to be tested and then peroxidase-labeled rabbit antibovine $\mathrm{IgG}$ and the indicator diaminobenzidine $-\mathrm{H}_{2} \mathrm{O}_{2}$ were added. The advantage of this test when compared with the IFA technique is that cultures can be evaluated by visible light microscopy and that preparations can be kept at room temperature for a long time. In their studies, Ressang et al. (1976a) found the indirect immunoperoxidase test and the indirect fluorescent antibody test equally sensitive. However, the evaluation of the indirect immunoperoxidase test needs some experience.

\section{F. Detection of BLV and BLV-Antigen}

Detection of BLV by electron microscopy or cocultivation and detection of BLV antigens by the ID test in short-term buffy-coat cells have been performed to see if an association exists between the presence of BLV antibodies and the presence of virus. Ferrer et al. (1974) examined 35 cattle and found a very close and direct correlation between the presence or absence of BLV antibodies and the presence or absence of virus. Only one of 20 in the IFA tested antibodypositive animals was negative for type $\mathrm{C}$ particles as determined by electron microscopy, and no BLV particles were observed in any of the buffy-coat cells derived from antibody-negative animals. Ressang et al. (1976a) took leukocyte samples for BLV isolation by cocultivation and electron-microscopic examination from 67 sero-positve (IFA) and 8 from serologically and hematologically negative animals. In 43 cocultures from sero-positive cows, BLV antigen could be detected whereas electron microscopy revealed type $\mathrm{C}$ particles in 32 of 58 samples. From the material of the serologically negative and hematologically normal animals, neither BLV antigen nor type $\mathrm{C}$ particles were found. Olson et al. (1973) cultivated lymphocytes from cows with precipitating antibodies against BLV ether treated antigen. Type C particles were observed in 99 lymphocyte cultures of 117 sero-positive animals. Mitscherlich et al. (1976) compared the presence of antibodies with the detection of antigen in leukocyte cultures. Forty leukocyte cultures from 41 ID-positive (ether-treated antigen) animals produced $\mathrm{BLV}$ antigen. In five cases, BLV antigen was detected in leukocyte cultures from sero-negative and hematologically normal animals. It would be interesting to know whether the sera of these five animals would have also reacted negatively in the ID test with gp69-antigen, or in one or other of the serologic tests discussed above.

The demonstration of BLV antigen in leukocyte cultures may be useful in studies on the pathogenesis of the disease, but the method is not practicable for routine diagnostic work since it demands cultivation of buffy-coat cells from each animal to be tested.

\section{Prospective Studies}

Mainly from morphologic observations, we consider BLV to be a bovine type $\mathrm{C}$ virus. To our present knowledge, however, BLV does not share antigenic determinants with structural proteins of other mammalian type $\mathrm{C}$ viruses. This disparity needs to be reinvestigated in future work using monospecific antisera against components of BLV; in addition, the question has to be settled regarding 
which of the polypeptides detected in BLV preparations are structural components, to clarify whether or not BLV exhibits a protein pattern different from that of other mammalian type $C$ viruses. In this connection, it would be desirable to study the high-molecular weight precursors of BLV proteins for comparison with those from other mammalian type $C$ viruses, which have already been characterised. Such studies should be supplemented by molecular hybridization experiments. Such data are necessary to decide whether BLV is the sole group member within the family Retroviridae, and if so, one must consider its possible origins. Is there, for example, an integration of BLV-RNA as a DNA provirus into the genome of species other than cattle?

The ability to detect infectious BLV by syncytia formation in tissue culture and to defect BLV antigens by serologic methods may stimulate investigations on the pathogenesis of bovine leukosis. Studies in this direction are important for transmission studies as well as to assess diagnostic methods applicable to eradication programs. We need to know the time between natural infection and the appearance of antibodies, and when, and for how long an infected animal becomes a potential carrier of infectious BLV. Two points are important in this respect - the percentage of infected animals producing BLV antibodies without clinical signs of the disease, i.e., persistent lymphocytosis and/or tumors, and whether such animals become virus carriers or recover completely from the infection with antibodies remaining. Besides these considerations, studies on the pathogenesis should include searching for BLV target cells and for mechanisms responsible for the pronounced suspectibility of certain cattle breeds to bovine leukosis.

For comparative leukemia research, the etiologic examination of sporadic and cutaneous forms of bovine leukosis would be worthwhile. These may be conditions in which BLV exists in a covert form.

Serologic studies give a strong impression that there is remarkably good agreement between the detection of BLV-specific antibodies and hematologic examination. Beyond that, antibody detection is a more sensitive indicator for BLV infection than the determination of elevated lymphocyte counts. Serologic diagnosis may soon replace, or at least supplement, hematologic diagnosis. It will be a subject of further investigation to determine the most sensitive method in terms of reliability and practicability for routine diagnostic work, coupled with the use of antigen(s) of high titer and specificity. In this respect, there may be a need to differentiate between the herd and single animal diagnosis. The next step will be a standardization of the appropriate serologic methods to be applied.

Acknowledgment. The authors are greatly indebted to Dr. A.P. Wyn-Jones for his help in the preparation of the manuscript.

\section{References}

Abramova, F.N., Koudratv, V.S., Sytinsky, I.A.: The biochemistry of leucosis in cattle. Vet. Bull. 44, 689-711 (1974)

Albrecht, A., Feige, M., Heinert, H., Mitscherlich, E., Schmidt, F.-W., van der Wall, G.: Ergebnisse des Immundiffusionstestes bei der Diagnose der Rinderleukose. Dtsch. Tierärztl. Wochenschr. 83, 311-350 (1976) 
August, J.T., Bolognesi, P., Fleissner, E., Gilden, R.V., Nowinski, C.: A proposed nomenclature for the virion proteins of oncogenic RNA viruses. Virology 60, 595-601 (1974)

Barthold, S.W., Baumgartener, L.E., Olson, C.: Brief communication: Lack of infectivity of bovine leukemia (C-type) virus to rats. J. Natl. Cancer Inst. 56, 643-644 (1976)

Bauer, $H$.: Virion and tumor cell antigens of $\mathrm{C}$-type RNA tumor viruses. In: Advances in Cancer Research, Vol. 20, Klein, G., Weinhouse, S., Haddow, A. (eds.). New YorkSan Francisco-London: Academic Press 1974, p. 275-341

Baumgartener, L.E., Olson, C., Miller, J.M., van der Matten, M.J.: Survey for antibodies to leukemia (C-type) virus in cattle. J. Am. Vet. Med. Assoc. 166, 249-251 (1975)

Bendixen, H.J.: Untersuchungen über die Rinderleukose in Dänemark. I. Vorkommen und Verbreitungsweise. Dtsch. Tierärztl. Wochenschr. 67, 4-7 (1960)

Bendixen, H.J.: Bovine enzootic leukosis. Adv. Vet. Sci. Comp. Med. 10, 129-204 (1965)

Bendixen, H.J.: The use of epizootiological experience as a guide for the study of etiologic pathogenesis and diagnosis of bovine leukosis. Vet. Microbiol. 1, 281-285 (1976)

Bolognesi, D.P., Bauer, H.: Polypeptides of avian RNA tumor viruses. I. Isolation and physical and chemical analysis. Virology 42, 1097-1112 (1970)

Calafat, J., Hageman, C., Ressang, A.A.: Structure of C-type virus particles in lymphocyte cultures of bovine origin. J. Natl. Cancer Inst. 52, 1251-1254 (1974)

Callahan, C., Lieber, M., Todaro, J., Graves, C., Ferrer, F.: Bovine leukemia virus genes in the DNA of leukemic cattle. Science 192, 1005-1007 (1976)

Chander, S.: Comparison between serological and hematological diagnosis of bovine leukosis. Vet. Microbiol. 1, 239-251 (1976)

Cornefert-Jensen, F., Hare, W.C., Stock, N.D.: Studies on bovine lymphosarcoma; Formation of syncytia and detection of virus particles in mixed cell cultures. Int. J. Cancer 4, 507-519 (1969)

Deshayes, L., Levy, D., Parody, A.L., Levy, J.P.: Proteins of bovine leukemia virus: I. Characterization and relationship with natural antibodies. J. Virol. 21, 1056-1060 (1977)

Devare, S.G., Stephenson, J.R., Sarma, P.S., Aaaronson, S.A., Chander, S.: Bovine lymphosarcoma: Development of a radioimmunologic technique for detection of the etiologic agent. Science 194, 1428-1430 (1976)

Dietzschold, B., Kaaden, O.R., Ueberschär, S., Weiland, F., Straub, O.C.: Suggestive evidence for an oncorna-virus-specific DNA polymerase from C-type particles of bovine leukosis. Z. Naturforsch. $29 c, 71-75$ (1974)

Diglio, C.A., Ferrer, J.F.: Induction of syncytia by the bovine C-type leukemia. Cancer Res. 36, 1056-1067 (1976)

Dutcher, R.M., Larkin, E.P., Marshak, R.R.: Virus-like particles in cow's milk from a herd with a high incidence of lymphosarcoma. J. Natl. Cancer. Inst. 33, 1055-1064 (1964)

Fenner, F.: Classification and nomenclature of viruses. Second report of the International Committee on Taxonomy of Viruses. Basel-München-Paris-London-New York-Sydney: S. Karger 1976

Ferrer, J.F., Stock, N.D., Lin, P.: Detection of replicating C-type viruses in continuous cell cultures established from cows with leukemia: Effect of the culture medium. J. Natl. Cancer Inst. 47, 613-621 (1971)

Ferrer, J.F.: Antigenic comparison of bovine type $\mathrm{C}$ virus with murine and feline leukemia viruses. Cancer Res. 32, 1871-1877 (1972)

Ferrer, J.F., Diglio, C.A.: Development of an in vitro infectivity assay for the C-ytpe bovine leukemia virus. Cancer Res. 36, 1068-1073 (1976)

Ferrer, J.F., Avila, L., Stock, N.D.: Serological detection of type C viruses found in bovine cultures. Cancer Res. 32, 1864-1870 (1972)

Ferrer, J.F., Abt, A.D., Bhatt, D.M., Marshak, R.R.: Studies on the relationship between infection with bovine C-type virus, leukemia and persistent lymphocytosis in cattle. Cancer Res. 34, 893-900 (1974)

Ferrer, J.F., Bhatt, D.M., Abt, D.A., Marshak, R.R., Baliga, V.L.: Serological diagnosis of infection with the putative bovine leukemia virus. Cornell Vet. 65, 527-542 (1975)

Flensburg, J.C., Streyffert, B.: The control of bovine leukosis in Denmark. Nord. Vet. Med. 29, 49-67 (1977) 
Frenzel, B., Mussgay, M., Schneider, L.G., Straub, O.C.: Immunofluorescence test for bovine leukosis-associated complement-fixing antibodies. Zbl. Vet. Med. B 22, 519-523 (1975)

Frenzel, B., Kaaden, O.R., Mussgay, M., Dietzschold, B., Straub, O.C., Weiland, F.: Detection of bovine leukosis associated antibodies by different tests. Bibl. Haematol. 43, 366-368 (1976)

Frenzel, B., Kaaden, O.R., Mussgay, M.: Purification of a glycoprotein from bovine leukemia virus (BLV). Z. Naturforsch. 32c, 301-304 (1977)

Gelderblom, H., Bauer, H., Bolognesi, D.P., Frank, H.: Morphogenese und Aufbau von RNA-Tumorviren: Elektronenoptische Untersuchungen an Viruspartikeln vom C-Typ. Zbl. Bakt. Abt. Orig. A 220, 79-90 (1972)

Gilden, R.V.: Interrelationships among RNA tumor viruses and host cells. Adv. Cancer Res. 22, 157-202 (1975)

Gilden, R.V., Long, C.W., Hanson, M., Toni, R., Charman, H.P., Oroszlan, S.: Characteristics of the major internal protein and RNA-dependent DNA polymerase of bovine leukaemia virus. J. Gen. Virol. 29, 305-314 (1975)

Gillespie, D., Gallo, R.C.: RNA processing and RNA tumor virus origin and evolution. Science 188, 802-811 (1975)

Gilette, K.G., Olson, C., Tekeli, S.: Demonstration of abnormal antigen in bovine lymphosarcoma by immunofluorescence. Am. J. Vet. Res. 30, 975-980 (1969)

Graves, C., Ferrer, F.: In vitro transmission and propagation of the bovine leukemia virus in monolayer cell cultures. Cancer Res. 36, 4152-4159 (1976)

Hehlmann, R.: RNA tumor viruses and human cancer. Curr. Top. Microbiol. Immunol. 73, 141-215 (1976)

Hoss, H.E., Olson, C.: Infectivity of bovine C-type (leukemia) virus for sheep and goats. Am. J. Vet. Res. 35, 633-637 (1974)

Irvin, A.D., Brown, C.G.D., Kanhai, G.K., Stagg, D.A.: Transplantation of bovine lymphosarcoma cells to athymic (nude) mice. Res. Vet. Sci. 22, 53-55 (1977)

Kaaden, O.R., Dietzschold, B., Straub, O.C.: Beitrag zur Isolierung einer RNA-abhängigen DNA-Polymerase aus Lymphozyten eines an lymphatischer Leukose erkrankten Rindes. Zentralbl. Bakteriol., Abt. Orig. 220, 101-105 (1972)

Kaaden, O.R., Dietzschold, B., Frenzel, B., Mussgay, M., Straub, O.C., Weiland, F.: Isolation of a precipitating antigen associated with bovine leukosis. Vet. Microbiol. 1, 121-128 (1976)

Kaaden, O.R., Frenzel, B., Dietzschold, B., Weiland, F., Mussgay, M.: Isolation of a p15 polypeptide from bovine leukemia virus and detection of specific antibodies in leukemic cattle. Virology 77, 501-509 (1977)

Kaaden, O.R., Frenzel, B., Weiland, F., Mussgay, M.: Charakterisierung des Virus der Rinderleukose und seiner Antigene. Zentralbl. Veterinaermed. (im Druck)

Kettmann, R., Mammerickx, M., Dekegel, D., Ghysdael, J., Portetelle, D., Burny, A.: Biochemical approach to bovine leukemia. Acta Haematol. 54, 201-209 (1975)

Kettmann, R., Portetelle, D., Mammerickx, M., Cleuter, Y., Dekegel, D., Galoux, M., Ghysdael, J., Burny, A., Chantrenne, H.: Bovine leukemia virus: An exogenous RNA oncogenic virus. Proc. Natl. Acad. Sci. U.S.A. 73, 1014-1018 (1976)

Levy, D., Guillemain, D., Deshayes, L., Parodi, A.L.: Serological investigations on bovine leukemia virus. Vet. Microbiol. 1, 253-258 (1976)

Mammerickx, M.: Sur l'utilisation du mouton pour les expériences sur la leucose bovine. Expér. anim. 3, 285-293 (1973)

Mammerickx, M., Portetelle, D., Kettmann, R., Ghysdael, J., Burny, A., Dekegel, D.: Comparative study of two diagnostic methods of bovine leukosis: Hematology and immunodiffusion. Vet. Microbiol. 1, 203-210 (1976)

McDonald, C., Ferrer, F.: Detection quantitation and characterization of the major internal virion antigen of the bovine leukemia virus by radioimmunoassay. J. Natl. Cancer Inst. 57, 875-882 (1976)

Miller, L.D., Miller, J.M.: Inoculation of calves with particles resembling C-type virus from cultures of bovine lymphosarcoma. J. Natl. Cancer Inst. 48, 423-427 (1972)

Miller, J.M., Olson, C.: Precipitating antibody to an internal antigen of the C-type virus associated with bovine lymphosarcoma. J. Natl. Cancer Inst. 49, 1459-1462 (1972) 
Miller, J.M., van der Maaten, M.J.: A complement-fixation test for the bovine leukemia (C-type) virus. J. Natl. Cancer Inst. 53, 1699-1702 (1974)

Miller, J.M., van der Maaten, M.J.: Serologic detection of bovine leukemia virus infection. Vet. Microbiol. 1, 195-202 (1976)

Miller, J.M., Miller, L.D., Olson, C, Gillette, K.G.: Virus-like particles in phytohemagglutinin-stimulated lymphocyte cultures with reference to bovine lymphosarcoma. J. Natl. Cancer Inst. 43, 1297-1305 (1969)

Miller, J.M., van der Maaten, M.J., Gustafson, G.H.: A comparison of the agar-gel diffusion and complement fixation test for bovine C-type (leukemia) virus. Proc. Am. Assoc. Vet. Lab. Diagnosis 207-214 (1974)

Mitscherlich, E., Plünnecke, A., Schmidt, F.W., Albrecht, H.: Techniques and results of immunodiffusion test in field trials. Vet. Microbiol. 1, 219-230 (1976)

Muscoplat, C.C., Johnson, D.W., Pomeroy, K.A., Olson, J.M., Larson, V.L., Stevens, J.B., Sorensen, D.U.: Lymphocyte surface immunoglobulin: Frequency in normal and lymphocyte cattle. Am. J. Vet. Res. 35, 593-595 (1974)

Mussgay, M., Kaaden, O.R.: Neuere Erkenntnisse über die Ätiologie und die serologische Diagnose der enzootischen Leukose des Rindes. Dtsch. Tierärztl. Wochenschr. 83, 351-353 (1976)

Ogura, H., Paulsen, J., Bauer, $H$. .: Cross neutralization of ovine and bovine C-type leukemia virus-induced syncytia formation. Cancer Res. 37, 1486-1489 (1977)

Olson, C.: Bovine lymphosarcoma (leukemia)-A synopsis. J. Am. Vet. Med. Assoc. 165, 630-632 (1974)

Olson, C., Baumgartener, L.E.: Lymphosarcoma (leukemia of cattle). The Bovine Practitioner 10, 15-22 (1975)

Olson, C., Baumgartener, L.E.: Pathology of lymphosarcoma in sheep induced with bovine leukemia virus. Cancer Res. 36, 2365-2370 (1976)

Olson, C., Miller, L.D., Miller, J.M., Hoss, H.E.: Brief communication: Transmission

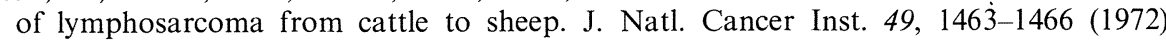

Olson, C., Hoss, H.E., Miller, J.M., Baumgartener, L.E. : Evidence of bovine C-type (leukemia) virus in dairy cattle. J. Am. Vet. Med. Assoc. 163, 355-357 (1973)

Onuma, M., Olson, C., Baumgartener, L.E., Pearson, L.D.: An ether-sensitive antigen associated with bovine leukemia virus infection. J. Natl. Cancer Inst. 55, 1155-1158 (1975)

Onuma, M., Olson, C., Driscoll, D.M.: Properties of two isolated antigens associated with bovine leukemia virus infection. J. Natl. Cancer Inst. 57, 571-578 (1976)

Parodi, A.-L., Levy, D., Guillemain, B., Irgens, K.: Recherche d'une méthode sérologique de dépistage de la leucose bovine. Bull. Off. int. Epiz. 85, 275-287 (1976)

Paulsen, J., Kuwilsky, S., Schliesser, T.: Antikörper gegen bovines und ovines C-Typ-Virus spezifisches Antigen in Seren von Rindern eines leukoseverseuchten Milchviehbestandes. (Vorläufige Mitteilung). Zentralbl. Veterinaermed B 20, 696-700 (1973)

Paulsen, J., Rudolph, R., Miller, J.M.: Antibodies to common ovine and bovine C-type virus specific antigen in serum from sheep with spontaneous leukosis and from inoculated animals. Med. Microbiol. Immunol. 159, 105-114 (1974)

Paulsen, J., Bertelsmann, K.F., Schliesser, Th.: Weitere Untersuchungen zum Vorkommen von Antikörpern gegen C-Typ-Virus spezifisches Antigen in Seren von Rindern aus leukoseverseuchten, -verdächtigen und -unverdächtigen Beständen. Zentralbl. Veterinaermed B 22, 596-605 (1975)

Paulsen, J., Rohde, W., Pauli, G., Harms, E., Bauer, H.: Comparative studies on ovine and bovine C-type particles. Bibl. Haemat. 43, 190-192 (1976)

Paulsen, J., Thiess, E., Schliesser, Th.: Zur serologischen Diagnose der Rinderleukose mit Hilfe der Komplementbindungsreaktion. Zentralbl. Veterinaermed., in press

Quigley, J.P., Rifkin, D.B., Reich, E.: Phospholipid composition of Rous sarcoma virus host cell membranes and other enveloped RNA viruses. Virology 46, 106-116 (1971)

Ressang, A.A., Mastenbroek, N., Quak, J., van Griensven, L.J.L.D., Calafat, J., Hilgers, J., Hageman, Ph.C., Soussi, T., Swen, S.: Studies on bovine leukemia, I. Establishment of type C-virus producing cell lines. Zentralbl. Veterinaermed. B 21, 602-617 (1974)

Ressang, A.A., Ellens, O.J., Mastenbroek, N., Quak, J., Miller, J.M., van der Maaten, M.J.: Studies on bovine leukaemia. II. Haematological. serological, virological and electron microscopical diagnosis. Zentralbl. Veterinaermed B 23, 566-579 (1976a) 
Ressang, A.A., Baars, I.C., Calafat, J., Mastenbroek, N., Quak, J.: Studies on bovine leukaemia. III. The haematological and serological response of sheep and goats to infection with whole blood from leukaemie cattle. Zentralbl. Veterinaermed. B 23, 662-668 (1976b)

Robertsson, J.A., Karlsson, K.-H., Hugosen, G.: Frequency of latent bovine leukosis in Sweden. Nord. Vet. Med. 29, 68-75 (1977)

Schmidt, F.W.: Preliminary report on transmission experiments of bovine leukosis by leukocyte-cultures. Bibl. Haematol. 36, 555-558 (1970)

Schmidt, F.W., Ueberschär, S., Tiefenau, M.: Viruspartikel in Leukozytenkulturen von experimentell infizierten Leukoserindern. Dtsch. Tierärztl. Wochenschr. 77, 451-452 (1970)

Schmidt, F.-W., Garcia de Lima, E., Mitscherlich, E., von Milczewski, K.E., Lembke, A.: Versuche zur Züchtung eines Agens der Rinderleukose in Leukozytenkulturen vom Rind. 3. Mitteilung: Leukoseübertragung durch zellfreies Kulturmedium auf Kälber. Zentralbl. Veterinaermed B 22, 673-686 (1975)

Stock, D., Ferrer, F.: Replicating C-Type virus in phytohemagglutinin-treated buffy-coat cultures of bovine origin. J. Natl. Cancer Inst. 48, 985-996 (1972)

Straub, O.C.: The difficulty in interpreting results of mouse transmission studies of bovine leukosis. Comparative Leukemia Research. Oxford-New York: Pergamon Press, 1965, pp. $245-249$

Straub, O.C.: Problems concerning the serological diagnosis of bovine leukosis. Submitted for publication (1977)

Straub, O.C., Weinhold, E. : Zur Frage der Übertragung boviner Leukose durch Kolostrum und Milch. Dtsch. Tierärztl. Wochenschr. 78, 441-444 (1971)

Straub, O.C., Weiland, F., Frenzel B.: Ergebnisse von hämatologischen und serologischen Untersuchungen bei natürlichen und experimentellen Rinderleukose-Übertragungsversuchen. Dtsch. Tierärztl. Wochenschr. 81, 549-604 (1974)

Straub, O.C., Lorenz, R.J., Chevrier, L., Donnelly, W.J.C., Flensburg, J.C., Gentile, G., Mammerickx, M., Markson, L.M., Ressang, A.A.: Bovine hematology. Parts I-III; in press (1977)

Tabel, H., Chander, S., van der Maaten, M.J., Miller, J.M. : Bovine leukosis V. Epidemiological study of bovine C-type virus by the use of the complement fixation test. Can. J. Comp. MED. 40, 350-354 (1976)

Tolle, A.: Zur Übertragbarkeit der Rinderleukose. Zentralbl. Bakteriol. Abt. Orig. 198, 142-149 (1965)

Ueberschär, S.: Elektronenoptische Untersuchungen an den Zellen der tumorösen Form der Leukose. Dtsch. Tierärztl. Wochenschr. 15/16, 417-422 (1963)

Van der Maaten, M.J., Miller, J.M.: Serological evidence of transmission of bovine leukemia virus to chimpanzees. Vet. Microbiol. 1, 351-357 (1976a)

Van der Maaten, M.J., Miller, J.M.: Replication of bovine leukemia virus in monolayer cell cultures. Bibl. Haematol. 43, 360-362 (1976b)

Van der Maaten, M.J., Miller, J.M., Boothe, A.D.: Replicating type-C virus particles in monolayer cell cultures of tissues from cattle with lymphosarcoma. J. Natl. Cancer Inst. 52, 491-498 (1974)

Weiland, F., Straub, O.C.: Frequency of surface immunoglobulin bearing blood lymphocytes in cattle affected with bovine leukosis. Res. Vet. Sci. 19, 100-102 (1975)

Weiland, F., Ueberschär, S.: Ultrastructural comparison of bovine leukemia virus (BLV) with C-ytpe particles of other species. Arch. Virol. 52, 187-190 (1976)

Weiland, F., Ueberschär, S., Straub, O.C., Kaaden, O.R., Dietzschold, B.: C-type particles in cultured lymphocytes from highly leukemic cattle. Intervirology 4, 140-149 (1974)

Wiesner, E.: Die Leukosen des Rindes. 2. Auflage. Jena: VEB Gustav Fischer Verlag 1967

Wittmann, W., Urbaneck, D.: Leukosen des Rindes. In: Handbuch der Virusinfektionen bei Tieren, Bd. V/1. Jena: Gustav Fischer Verlag 1969a

Wittmann, $W$., Urbaneck, D.: Untersuchungen zur Ätiologie der Rinderleukose. 8. Übertragungsversuche mit Blut leukosekranker Rinder auf Schaflämmer (Kurzmitteilung). Arch. Exp. Veterinaermed. (B) 23, 709-713 (1969b) 